\title{
Adhesivity of Bio- Based Anhydrous Citric Acid, Tannin-Citric Acid and Ricinoleic Acid in the Properties of Formaldehyde- Free Medium Density Particleboard (MDP)
}

\section{Mogućnost primjene ekološki prihvatljivoga anhidrida limunske kiseline, taninsko- limunske kiseline i ricinoleinske kiseline kao ljepila za proizvodnju iverica srednje gustoće (MDP) bez formaldehida}

Original scientific paper $\bullet$ Izvorni znanstveni rad

Received-prispjelo: 12. 3. 2019.

Accepted-prihvaćeno: 28. 4. 2020.

UDK: $630 * 863.21$

https://doi.org/10.5552/drvind.2020.1917

(C) 2020 by the author(s). Licensee Faculty of Forestry, University of Zagreb. This article is an open access article distributed under the terms and conditions of the Creative Commons Attribution (CC BY 4.0) license.

\begin{abstract}
Particles of flooded gum (Eucalyptus grandis) were bonded using three bio-based adhesives anhydrous citric acid (CA), tannin-citric acid (TCA) and ricinoleic acid (RA) - from renewable sources and hot pressed to produce medium density particleboard (MDP). The bonding capacity of such adhesives and properties of the MDP were evaluated and compared to the requirements of seven grades of particleboards, according to the EN 312 (2010) standard. The RA did not create adhesion reaction with the wood particles. Adhesives formulated with $C A$ and TCA presented capacity to bond eucalyptus particles into MDP confirmed by esterification reactions of the FTIRS analysis. MDP bonded with CA met requirements as high as grade P5 of the EN 312 (2010) standard for static modulus of elasticity (MOE) and internal bond (IB) and P2 for modulus of rupture (MOR). Panels bonded with TCA met requirements up to grade P3 for MOE, however, did not withstand water absorption.
\end{abstract}

Keywords: Eucalyptus grandis; bio-based adhesives; particleboards; bonding capacity; FTIR analysis; EN requirements

\footnotetext{
Authors are researchers at Forest Products Laboratory, Brazilian Forest Service, Brasília, Brazil.

${ }^{2}$ Authors are researchers at Chemistry Institute, University of Brasilia, Brasília, Brazil.
} 
SAŽETAK • Za izradu iverice srednje gustoće (MDP) upotrijebljeno je iverje drva eukalipta (Eucalyptus grandis) lijepljeno trima ekološki prihvatljivim ljepilima dobivenim iz obnovljivih izvora na bazi anhidrida limunske kiseline (CA), taninsko-limunske kiseline (TCA) i ricinoleinske kiseline (RA) te prešano u vrućoj preši. Kvaliteta lijepljenja tim ljepilima i svojstva iverice ocijenjeni su usporedbom sa sedam klasa uporabe prema normi EN 312 (2010). Ljepilo RA nije uspjelo povezati drvno iverje. Ljepila CA i TCA pokazala su sposobnost lijepljenja eukaliptova iverja pri izradi MDP ploče, što je potvrđeno reakcijom esterifikacije u FTIR analizi. MDP ploča izrađena primjenom CA ljepila udovoljava visokim zahtjevima klase uporabe P5 prema EN 312 (2010) za modul elastičnosti (MOE) i čvrstoću na raslojavanje (IB) te klase P2 za modul loma (MOR). Ploče izrađene uporabom TCA ljepila ispunile su zahtjeve klase uporabe P3 za modul elastičnosti (MOE), ali nisu zadovoljile zahtjeve o upijanju vode.

Ključne riječi: Eucalyptus grandis; ekološki prihvatljiva ljepila; iverice; sposobnost lijepljenja, FTIR analiza, EN zahtjevi

\section{INTRODUCTION 1. UVOD}

Medium Density Fiberboard (MDF), Hardboard or fiberboard (HB) and High Density Fiberboard (HDF) are reconstituted wood-based panels composed of wood fibers, while Medium Density Particleboard (MDP) is produced with wood particles and adhesive, pressed under high pressure and temperature. MDF and HDF are produced with the addition of a synthetic adhesive using a dry process and their density ranges from 600 to $900 \mathrm{~kg} / \mathrm{m}^{3}$, and HB results from hot pressing that uses a wet process without the addition of adhesives that reactivates the natural binders of wood, such as lignin.

MDP is a popular composite with density ranging from 551 to $750 \mathrm{~kg} / \mathrm{m}^{3}$, which presents high use of wood raw material, mainly from planted forests, at affordable price, with broad application in the furniture industry, construction/remodeling and handmade articles in replacement of solid wood (FAO, 2017).

MDP and MDF are currently the most consumed wood-based reconstituted panels worldwide (FAO, 2017). The Brazilian production of reconstituted woodbased panels in 2018 was 8.2 million $\mathrm{m}^{3}, 40 \% \mathrm{MDP}$ and $60 \% \mathrm{MDF} / \mathrm{HDF}$. The production of $\mathrm{MDF} / \mathrm{HDF}$ and $\mathrm{HB}$ dropped $2.5 \%$ and $0.4 \%$, respectively; MDP increased $3.4 \%$ (IBÁ, 2019).

The Brazilian wood-based panel sector ranked $8^{\text {th }}$ place in 2018 in the global market of largest producers, the same position as the previous year (IBÁ, 2019).

Formaldehyde-based synthetic resins are the most used adhesives in the production of reconstituted woodbased panels, especially urea-, phenol- and melamineformaldehyde, and the combination of these resins. The formaldehyde acts as the catalyst of the resin setting.

According to Silva et al. (2013), the urea-formaldehyde adhesive is the most significant input to environmental impacts of reconstituted panels, such as abiotic resources depletion, eutrophication, ozone photochemical formation, acidification and global warming. Furthermore, chemical compounds based on formaldehyde are classified by the International Agency for Research on Cancer (IARC) as carcinogenic, tumorigenic and teratogenic. According to IARC (2006), historically, the major source of formaldehyde gas release in dwellings is urea-formaldehyde derived from insulation panels. That is why the replacement of formaldehyde-based adhesives is currently in demand and requires research into developing new and sustainable adhesives, especially bio-based ones that should be biodegradable, non-polluting, derived from renewable sources and economically feasible.

In this context, previous publications on the use of citric acid as a bio-based adhesive in MDP have presented promising results (Umemura et al., 2012a, b, 2013; Liao et al., 2016; Kusumah et al., 2016). Although the adhesion mechanism with citric acid is yet not well known, acts as a cross-linking agent, forming ester bonds with wood biopolymers (Yang et al., 1996; Zagar and Grdadolnik 2003; Umemura et al., 2013, 2015; Widyorini et al., 2016; Kusumah et al., 2016).

Tannins are also an alternative for formaldehydebased resins, due to the large number of phenolic rings in its structure (Santana and Teixeira, 1996; Chupin et al., 2013). Zhao et al. (2015) investigated the effects of citric acid on the curing properties of tannin-sucrose adhesives and concluded that the addition of citric acid promotes the reaction between tannin and sucrose at lower temperatures. Ricinoleic acid is also from a renewable source, derived from castor bean oil, which could be used to form polyesters (Péres et al., 2014) and, probably, be used as a natural adhesive in particleboards.

Environmental and human health benefits are the main advantage of these three compounds, as they are formaldehyde-free, non-toxic and non-polluting substances. They are also derived from renewable resources and can generate biodegradable materials. Consequently, the application of such materials in the industry can reduce the environmental impact and minimize the demand for petroleum products.

Considering the above, the present work aims at evaluating the properties of MDP made with eucalyptus particles bonded with three bio-based adhesives based on ricinoleic acid, anhydrous citric acid and tannin-citric acid.

\section{MATERIALS AND METHODS}

\section{MATERIJALI I METODE}

\subsection{Particles processing}

2.1. Proizvodnja iverja

Eucalyptus grandis flakes were hammer-milled and classified into particles after passing through a set of screen sieves. Then, particles were classified in a 
vibrating sieve by a set of sieves of 20, 40 and 60 mesh. Particles retained in the 40 mesh sieve were used in the panels production.

In order to evaluate if the proposed pressing temperature of MDPs was adequate, thermal analysis of the particles was performed using a thermogravimetric analyzer Shimadzu, model DTG- $60 \mathrm{H}$ at a heating rate of $10{ }^{\circ} \mathrm{C} / \mathrm{min}$ from $25^{\circ} \mathrm{C}$ to $800{ }^{\circ} \mathrm{C}$ with nitrogen flow of $30 \mathrm{~mL} / \mathrm{min}$.

\subsection{Preparation of adhesive solutions}

2.2. Priprema ljepila

For the manufacture of the medium density particleboard, three formulations of adhesives were used: anhydrous citric acid (CA), tannin-citric acid (TCA) and ricinoleic acid (RA).

Anhydrous Citric Acid (CA) at $99.5 \%$ purity level was purchased from food suppliers. The CA adhesive formulation was prepared by mixing water and CA at a ratio of 1:1 (mass:mass). The viscosity of the solution was measured in a rotational Brookfield DV-IPrime viscometer for small samples using \#18 spindle, at the speed of 100 RPM and room temperature of $(27 \pm 2)^{\circ} \mathrm{C} . \mathrm{A} \mathrm{pH}$ indicator tape was used to measure the solution $\mathrm{pH}$. The $\mathrm{CA}$ formulation presented $\mathrm{pH}$ of 1 and viscosity of $74 \mathrm{cP}$.

For the preparation of the ricinoleic acid (RA), castor bean oil was saponified with $\mathrm{NaOH}$ solution, followed by acidification with $\mathrm{HCl}$, according to the methodology used by Péres et al. (2014).

The tannin-citric acid adhesive (TCA) was prepared as an aqueous solution by dissolving citric acid and tannin in water. Initially, the tannin was diluted in water at a ratio $1: 1$ (mass:mass) at $50^{\circ} \mathrm{C}$ until complete solubilization, and then the citric acid was added at the same ratio.

\subsection{Manufacture of MDPs}

\subsection{Izrada MDP ploča}

The adhesive solutions were sprayed onto selected particles $(-40$ mesh +60 mesh) in a rotatory drum mixer, and the furnish was subsequently dried at $60^{\circ} \mathrm{C}$, for 6 hours, to $9 \%$ moisture content (determined in a moisture meter thermobalance model BEL). The mat was hand formed and hot pressed at $(180 \pm 3){ }^{\circ} \mathrm{C}$ for 10 minutes under the pressure of $4 \mathrm{MPa}$. Single-layer flat boards were produced with dimensions of $30 \mathrm{~cm}$ (length) $\times 30 \mathrm{~cm}$ (width) $\times 1$ (thickness) $\mathrm{cm}$. The three adhesive solutions (CA, TCA and RA), as described above, were tested at a concentration of $18 \%$ based on the dry mass of particles (Table 1).

For each treatment, three panels were produced, from which five specimens were cut for each test. The panels were conditioned in a climate room with controlled conditions of relative humidity $(60 \pm 2) \%$ and temperature $(20 \pm 1){ }^{\circ} \mathrm{C}$ to reach equilibrium moisture content.

\subsection{MDP characterization}

2.4. Karakterizacija MDP ploča

The physical properties evaluated were density (EN 323:1993), water absorption (WA) and thickness swelling (TS) after 24 hours immersion in water (EN $317: 1993)$. For the evaluation of mechanical properties, the internal bonding (IB) (EN 319:1993), modulus of elasticity $(M O E)$ and modulus of rupture $(M O R)$ in static bending (EN 310:1993) were determined. The panels were classified according to the requirements of EN 312:2010 standard, which establishes seven grades of particleboards.

The experiment was carried out in a completely randomized design (CRD). Statistical analysis was conducted using the t-student test at $5 \%$ significance level.

\subsection{Scanning Electron Microscopy (SEM) \\ 2.5. Pretražni elektronski mikroskop (SEM)}

Samples of particles and particles detached from panels were analyzed by Scanning Electron Microscopy (SEM), using a Field Emission Electron Microscope (JEOL, JSM-7001 F) operating at $15 \mathrm{kV}$. For SEM analysis, particles were pre-treated by sputter coating with gold.

\subsection{Carbon-Hydrogen-Nitrogen analysis}

2.6. Ugljik-vodik-dušik analiza

The Carbon-Hydrogen-Nitrogen (CHN) analyses were carried out in an Elemental Analyzer Perkin Elmer, model EA 2400 Series II, aiming to evaluate the carbon gain $(C G)$ that was calculated by equation 1 , and expressed as mean values of three measurements:

$$
\% C G=\frac{(\% C A P-\% C B P)}{\% C B P} \times 100
$$

Where:

$\% C G$ - carbon gain after pressing;

$\% C A P$ - carbon content in eucalyptus particles after pressing;

$\% C B P$ - carbon content in eucalyptus particles before pressing.

\subsection{FTIR analysis \\ 2.7. FTIR analiza}

Samples from non-treated particles and from particleboards were ground in a hammer mill and then pelleted in Potassium bromide ( $\mathrm{KBr})$. The $\mathrm{KBr}$ disks were analyzed by Fourier Transform Infrared (FTIR) spec-

Table 1 Description of MDP manufacturing parameters

Tablica 1. Parametri izrade MDP ploča

\begin{tabular}{|l|c|c|c|}
\hline \multicolumn{1}{|c|}{ Adhesive / Ljepilo } & $\begin{array}{c}\text { Pressing conditions } \\
\text { Uvjeti prešanja }\end{array}$ & $\begin{array}{c}\text { Adhesive } \\
\text { Ljepilo, } \%\end{array}$ & $\boldsymbol{\rho}^{*}, \mathbf{g}^{\prime} / \mathbf{c m}^{\mathbf{3}}$ \\
\hline Anhydrous citric acid (CA) / anhidrid limunske kiseline (CA) & $180^{\circ} \mathrm{C} / 10 \mathrm{~min}$ & 18 & 0.80 \\
\hline Ricinoleic acid (RA) / taninsko-limunska kiselina (TCA) & $180^{\circ} \mathrm{C} / 10 \mathrm{~min}$ & 18 & 0.80 \\
\hline Tannin-citric acid (TCA) / ricinoleinska kiselina (RA) & $180^{\circ} \mathrm{C} / 10 \mathrm{~min}$ & $9(\mathrm{CA}) / 9(\mathrm{TAN})$ & 0.80 \\
\hline
\end{tabular}

$* \rho$ - target apparent density (at $12 \%$ moisture content) / $\rho$ - ciljana prividna gustoća (pri $12 \%$ sadržaja vode); TAN - tannin / TAN-tanin 
troscopy in the mid-infrared spectrum $\left(4000-400 \mathrm{~cm}^{-1}\right)$ using a Shimadzu spectrometer, model IR Prestige-21.

\section{RESULTS AND DISCUSSION} 3. REZULTATI I RASPRAVA

\subsection{DTG analysis}

\subsection{DTG analiza}

The TG and DTG curves of eucalyptus particles indicated three bands of thermal degradation (Figure 1), the first (from $25^{\circ} \mathrm{C}$ to $89^{\circ} \mathrm{C}$ ) corresponding to approximately $7.13 \%$ of mass loss, was attributed to moisture loss. The two others were attributed to the degradation of hemicellulose and cellulose (from 230 ${ }^{\circ} \mathrm{C}$ to $362{ }^{\circ} \mathrm{C}$ ) and lignin deterioration $\left(364{ }^{\circ} \mathrm{C}\right.$ to 510 ${ }^{\circ} \mathrm{C}$ ), as lignin is the most resistant biopolymer of lignocellulosic materials (Seye et al., 2010).

In the temperature range of $100-220^{\circ} \mathrm{C}$, the mass loss was about $0.82 \%$. According to Randriamanantena et al. (2009), this range corresponds to the zone of thermal stability, which is limited by the initial thermal degradation temperature of the main components of wood. This indicates that the ideal temperature for pressing eucalyptus particleboards should be in between this range.

\subsection{SEM analysis}

\subsection{SEM analiza}

Non-treated particles presented apparent pores, which is typical of lignocellulosic materials (Figure 2a), while particles from panels with ricinoleic acid, anhydrous citric acid and tannin-citric acid were covered by the adhesives and presented more heterogeneous surfaces (Figure 2b, c, d). Comparing to other treatments, particles covered by RA (Figure $2 \mathrm{~b}$ ) presented more loose fibril bundles. This analysis is import to under- stand the ability of the particles to be bonded to the adhesives and how the pores are filled up.

\subsection{MDP properties}

3.3. Svojstva MDP ploča

Particleboards bonded with RA did not present sufficient adhesion even after being pressed at $180{ }^{\circ} \mathrm{C}$ for 10 minutes. As a result, it was not possible to characterize RA bonded particleboards. Compared to CA panels, TCA particleboards presented visibly lower adhesion and particles were easily detached and presented rougher surface.

After the water immersion test, the specimens of TCA bonded panels disintegrated into loose particles indicating that the adhesive was not resistant to water. Thus, it was impossible to measure TS and WA. However, CA particleboards maintained their integrity after immersion in water but they did not achieve the minimum requirements of the EN 312:2010 for TS. The resistance of CA particleboards against water can be explained by Vukusic et al. (2006), who described the chemical reaction between CA and wood cellulose, in which hydrophobic esters groups replaced some hydrophilic groups of wood biopolymer, reducing the absorption of water by wood particles.

According to Table 2, there is no significant difference in apparent density of CA and TCA treatments. The moisture content of both treatments met the requirements specified by the EN 312:2010 standard.

All mechanical properties (MOR, MOE and $I B)$ of panels bonded with CA were higher than those of panels bonded with TCA, indicating that this treatment presented better adhesion. Taking into account the requirements of EN 312:2010 standard, in general MDPs produced with anhydrous citric acid are graded as panels to be used in dry conditions (P2 boards). Neverthe-

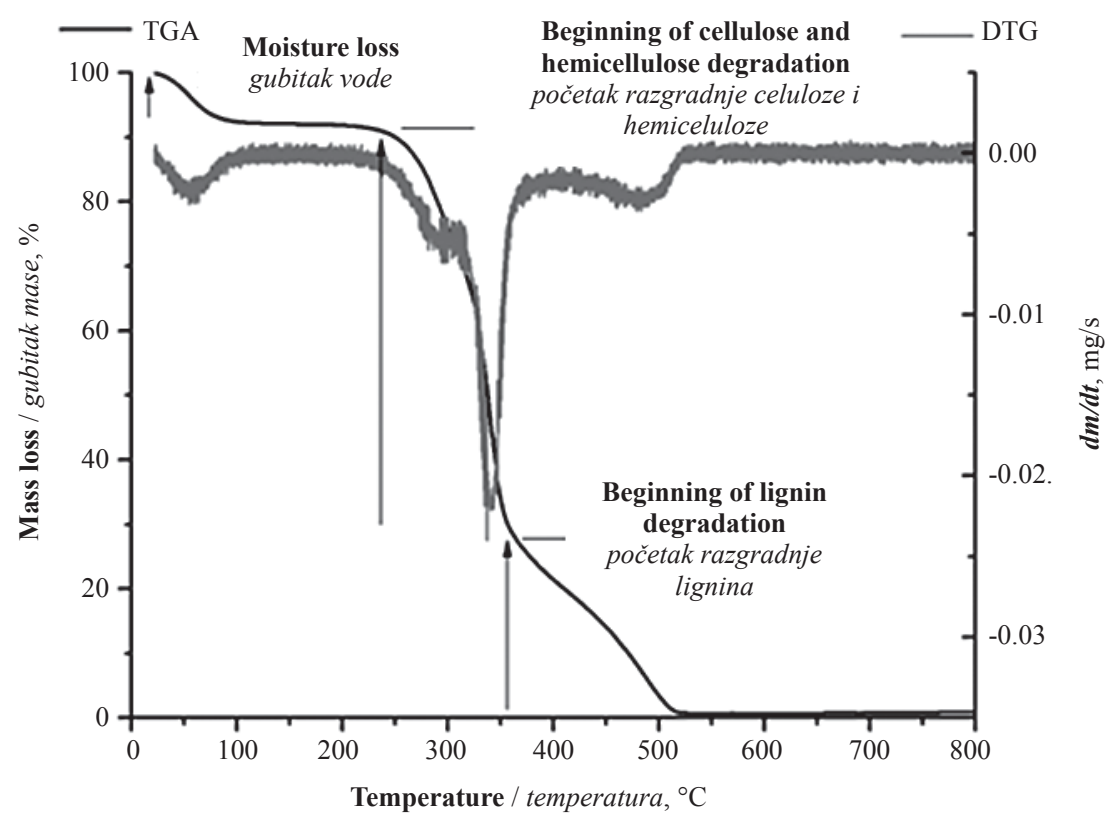

Figure 1 Thermogravimetric analysis (TGA) and derivative thermogravimetric (DTG) curve of eucalyptus particles "in natura"

Slika 1. Termogravimetrijska analiza (TGA) i derivirana termogravimetrijska (DTG) krivulja iverja prirodnog drva eukalipta 


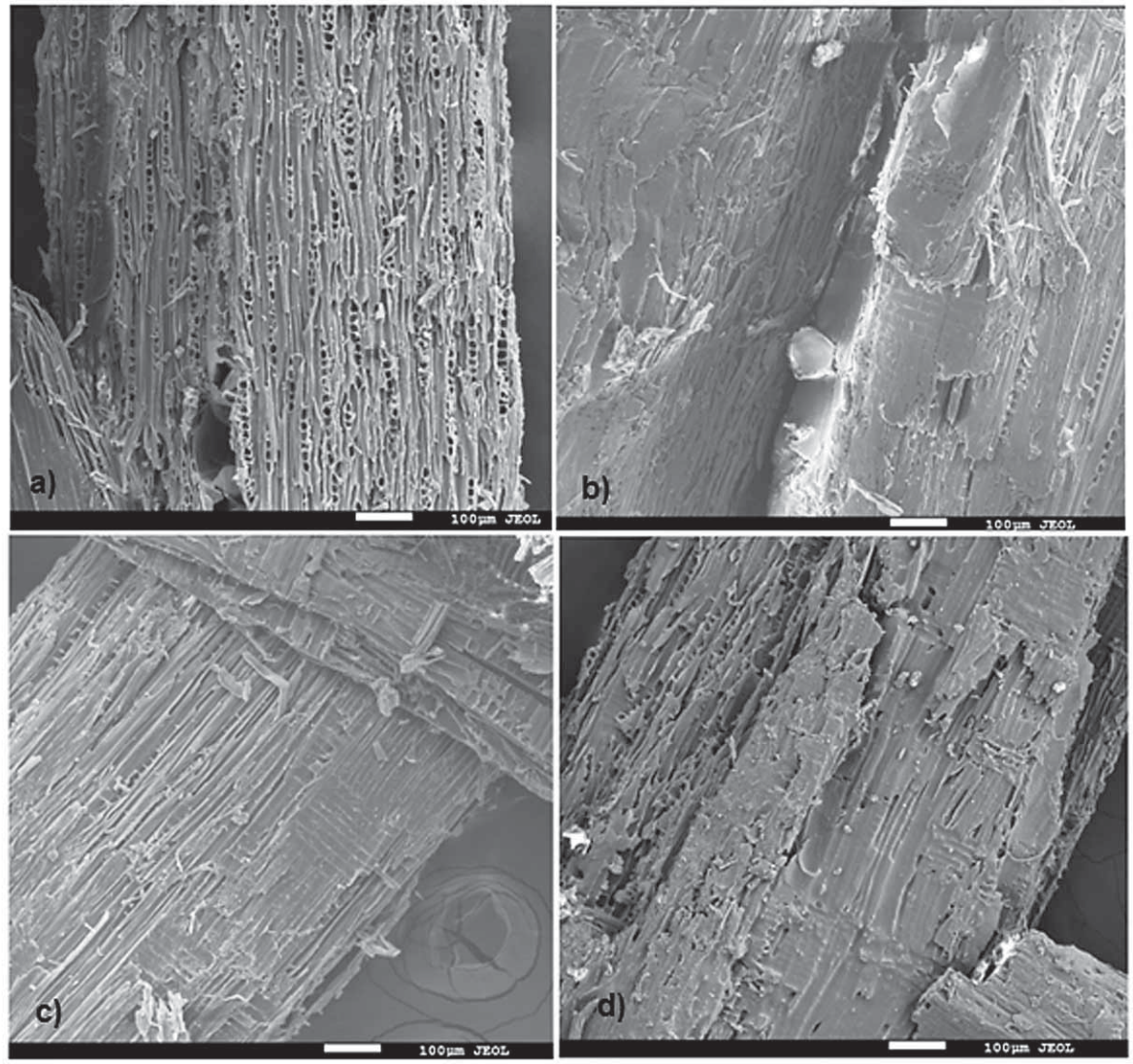

Figure 2 Micrographs of particles detached from panels after pressing. a) eucalyptus particle ("in natura"); b) eucalyptus particle with ricinoleic acid resin; c) eucalyptus particle with anhydrous citric acid resin; d) eucalyptus particle with tannincitric acid resin

Slika 2. Mikrofotografije iverja odvojenoga iz ploča nakon prešanja: a) iverje drva eukalipta (prirodno); b) iverje drva eukalipta sa smolom ricinoleinske kiseline; c) iverje drva eukalipta sa smolom anhidrida limunske kiseline; d) iverje drva eukalipta sa smolom taninsko-limunske kiseline

less, considering only mechanical properties $(M O R$, $M O E$ and $I B)$, they were graded as load bearing boards to be used in humid conditions (P5 boards). As for the panels bonded with tannin-citric acid they did not meet the minimum requirements for $I B$ and $M O R$, while the requirements of non-load bearing boards were met for MOE.

The temperature and pressure applied in CA particleboards were sufficient to promote polymerization re- actions between the citric acid molecules and wood molecules. It is likely that, due to polyesterification reactions, the adhesiveness was between carboxylic groups of citric acid and the hydroxyl groups of wood biopolymers (lignin, cellulose and hemicellulose) (Figure 3). According to Mano and Mendes (1999), molecules with functional groups that are prone to reactions by three or more points, which is the case of citric acid, may create crosslinked polymers with thermosetting characteristics.

Table 2 Means and coefficient of variation of physical and mechanical properties of MDPs

Tablica 2. Srednje vrijednosti i koeficijenti varijacije fizičkih i mehaničkih svojstava MDP ploča

\begin{tabular}{|c|c|c|c|c|c|c|c|}
\hline $\begin{array}{c}\text { Adhesive } \\
\text { Ljepilo }\end{array}$ & $\rho, \mathrm{g} / \mathrm{cm}^{3}$ & $\begin{array}{l}\text { Modulus of } \\
\text { rupture } \\
\text { MOR } \\
\text { Modul loma } \\
\text { MOR } \\
\text { MPa }\end{array}$ & \begin{tabular}{|c} 
Modulus of \\
elasticity \\
MOE \\
Modul \\
elastičnosti \\
MOE \\
MPa \\
\end{tabular} & $\begin{array}{c}\text { Internal } \\
\text { bonding } \boldsymbol{I B} \\
\check{C} \text { vrstoća na } \\
\text { raslojavanje } \\
\text { IB } \\
\mathrm{MPa}\end{array}$ & $\begin{array}{c}\text { Moisture } \\
\text { content } \\
\text { MC } \\
\text { Sadržaj } \\
\text { vode } M C \\
\%\end{array}$ & $\begin{array}{c}\text { Thickness } \\
\text { swelling } \\
\text { TS24h } \\
\text { Debljinsko } \\
\text { bubrenje } \\
\text { TS24h } \\
\% \\
\end{array}$ & $\begin{array}{c}\text { Water } \\
\text { absorption } \\
\text { WA24h } \\
\text { Upojnost } \\
\text { vode } \\
\text { WA24h } \\
\% \\
\end{array}$ \\
\hline $\begin{array}{l}\text { Ricinoleic acid (RA) } \\
\text { ricinolenska kiselina (RA) }\end{array}$ & NA* & $\mathrm{NA}$ & NA & $\mathrm{N}$ & $\mathrm{NA}$ & NA & NA \\
\hline $\begin{array}{l}\text { Anhydrous citric acid (CA) } \\
\text { anhidrid limunske kiseline (CA) }\end{array}$ & $\begin{array}{c}0.80^{a^{* *}} \\
(5.6)^{* * *}\end{array}$ & $\begin{array}{l}12.04^{\mathrm{b}} \\
(10.7)\end{array}$ & $\begin{array}{l}2,823.8^{\mathbf{b}} \\
(7.5)\end{array}$ & $\begin{array}{l}0.49^{\mathrm{b}} \\
(16.6)\end{array}$ & $\begin{array}{c}10.17^{\mathrm{b}} \\
(4.1)\end{array}$ & $\begin{array}{c}22.04 \\
(4.7)\end{array}$ & $\begin{array}{l}52.8 \\
(8.9)\end{array}$ \\
\hline $\begin{array}{l}\text { Tannin-citric acid (TCA) } \\
\text { taninsko-limunska kiselina (TCA) }\end{array}$ & $\begin{array}{l}0.80^{\mathrm{a}} \\
(6.8)\end{array}$ & $\begin{array}{l}9.37^{\mathrm{a}} \\
(24.0)\end{array}$ & $\begin{array}{l}2,201.0^{\text {a }} \\
(24.7)\end{array}$ & $\begin{array}{l}0.24^{\mathrm{a}} \\
(32.0)\end{array}$ & $\begin{array}{l}9.27^{\mathrm{a}} \\
(2.5)\end{array}$ & NA & NA \\
\hline
\end{tabular}

*NA - not available / NA - nije dostupno

**Mean values followed by the same letter in the same column are not significantly different by the $t$-student test at $5 \%$ significance level. / Ako se iza srednjih vrijednosti u istom stupcu nalazi isto slovo, tada se one ne razlikuju značajno uz razinu značajnosti od $5 \%$ prema t-testu. ***Numbers in parenthesis are coefficients of variation, \%. / Brojevi u zagradama koeficijenti su varijacije, \%. 


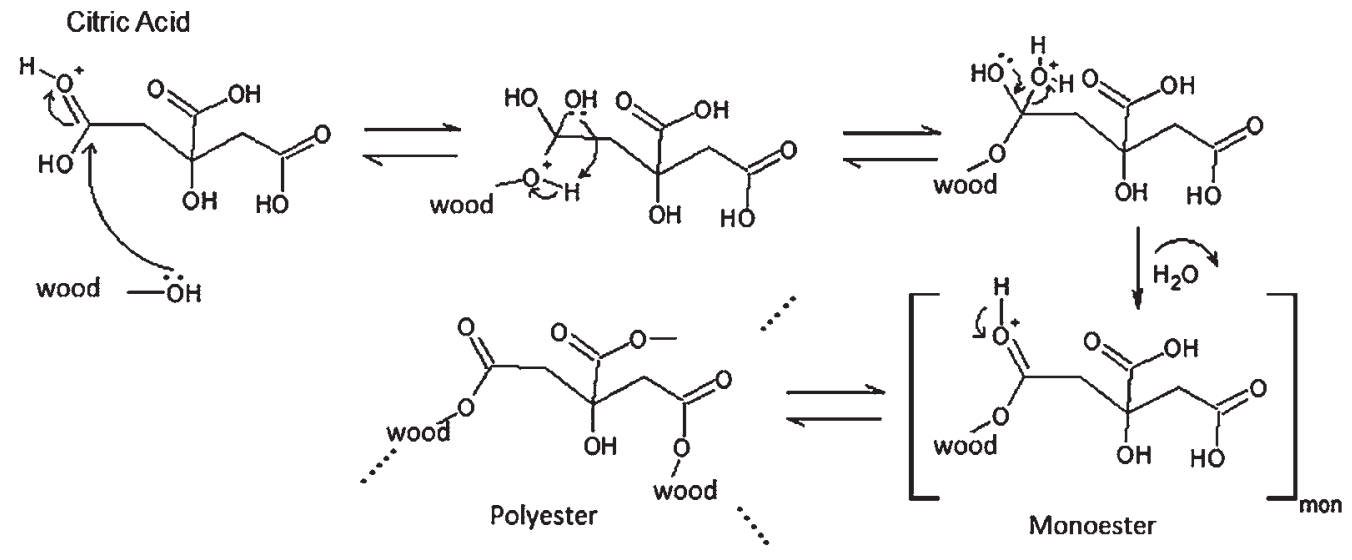

Figure 3 Proposed scheme of polyesterification reaction in anhydrous citric acid bonded particleboards

Slika 3. Predložena shema reakcije poliesterifikacije u ivericama izrađenima primjenom ljepila na bazi anhidrida limunske kiseline

In particleboards bonded with tannin-citric acid, the most probable adhesion mechanism is also polyesterification between citric acid, tannin and the hydroxyl groups of wood biopolymers. However, it is more likely that reactions between tannin and citric acid molecules took place, since the tannin is more accessible than wood biopolymers. This can explain why samples disintegrated into loose particles after water immersion.

The particles of panels bonded with ricinoleic acid did not create adhesion reaction, even in the presence of two functional groups (carboxyl and hydroxyl) prone to esterification reaction with the hydroxyl sites of wood biopolymers. It may be stated that pressing conditions were not sufficient to promote such esterification reaction. Furthermore, Péres et al. (2014) obtained a biopolyester of ricinoleic acid, without catalysts, only after six hours of reaction in a reactor at 190 ${ }^{\circ} \mathrm{C}$. Additionally, the molecule of ricinoleic acid is larger than that of citric acid, which may hinder the linking process with wood hydroxyls.

\subsection{CHN elemental analysis}

\subsection{Elementarna analiza $\mathrm{CHN}$}

The carbon gain $(C G)$ after pressing the particleboard was $0.4 \%$ with CA and $3.91 \%$ with TCA (Table $3)$. These results are an indicator that esterification reaction took place in the pressed glued particles.

Table 3 Carbon-Hydrogen-Nitrogen analysis of eucalyptus particles

Tablica 3. Ugljik-vodik-dušik analiza iverja drva eukalipta

\begin{tabular}{|l|c|c|c|c|}
\hline Particle / Iverje* & $\mathbf{\% C}$ & $\mathbf{\% H}$ & $\mathbf{\% N}$ & $\mathbf{\%} \boldsymbol{C G}^{* *}$ \\
\hline E & 45.80 & 6.05 & 0.14 & - \\
\hline CA & 46.00 & 5.92 & 0.11 & 0.44 \\
\hline TCA & 47.59 & 6.14 & 0.18 & 3.91 \\
\hline
\end{tabular}

*E - untreated eucalyptus particles ("in natura"); CA - eucalyptus particles bonded with anhydrous citric acid; TCA - eucalyptus particles bonded with tannin-citricacid / $E$ - prirodno iverje drva eukalipta; CA - iverje drva eukalipta lijepljeno anhidridom limunske kiseline; TCA - iverje drva eukalipta lijepljeno taninsko-limunskom kiselinom

** CG - carbon gain / dobitak ugljika

\subsection{FTIR analysis}

\subsection{FTIR analiza}

The IR spectra of eucalyptus particles "in natura" presented a larger band in the region of $3400 \mathrm{~cm}^{-1}$ (Figure 4a), which indicates the presence of O-H stretch.

The fingerprint region between $1725-1740 \mathrm{~cm}^{-1}$ presented a peak, which is related to axial stretching of carbonyl groups $(\mathrm{C}=\mathrm{O})$ in carboxylic acid groups. The $1050 \mathrm{~cm}^{-1}$ band corresponds to stretches of the $\mathrm{C}-\mathrm{O}$ group of celluloses, hemicelluloses and lignin or to the C-O-C groups of hemicellulose (Brum et al., 2008).

The bands of IR spectra at $1508 \mathrm{~cm}^{-1}$ and 1430 $\mathrm{cm}^{-1}$ are related to the aromatic ring vibrations of the guaiacyl present in lignin (Hergert, 1971). The bands observed below $1000 \mathrm{~cm}^{-1}$ correspond to hydroxyl groups of cellulose (Castro et al., 2004).

Regarding CA bonded particleboards (Figure 4b), peaks of IR spectra were observed in four characteristic bands indicating esterification reactions. The first was a strong and prominent peak in band $1737 \mathrm{~cm}^{-}$ ', corresponding to the carbonyl stretching $(\mathrm{C}=\mathrm{O})$ of ester. The second was a peak in the band at $1374 \mathrm{~cm}^{-1}$, corresponding to $\mathrm{CH}$ bonds of $\mathrm{CH}_{3}$ groups. The third was a peak in between $1200-1350 \mathrm{~cm}^{-1}$, indicating stretching the $\mathrm{C}-\mathrm{O}$ bond of $-\mathrm{O}-(\mathrm{C}=\mathrm{O})-$. The last peak was in the bands between 1010-1150 $\mathrm{cm}^{-1}$, corresponding to stretches of C-O bonds (Pavia et al., 2008.). There was also a broad band in the region between $3200-3600 \mathrm{~cm}^{-1}$, corresponding to the axial deformation of O-H groups. This can be attributed to the presence of water or to the hydroxyls of wood that were not chemically bonded with the citric acid.

Particleboards bonded with TCA adhesive (Figure 4c) have also shown IR spectra with a broad peak in the band between $3200-3600 \mathrm{~cm}^{-1}$. TCA particleboards presented peaks between bands $1010-1150 \mathrm{~cm}^{-1}$ and in between 1200-1350 $\mathrm{cm}^{-1}$. However, when compared to CA bonded particleboards, there was no evidence of a strong peak at the band $1737 \mathrm{~cm}^{-1}$, indicating less esterification reactions between particles and TCA adhesive. 

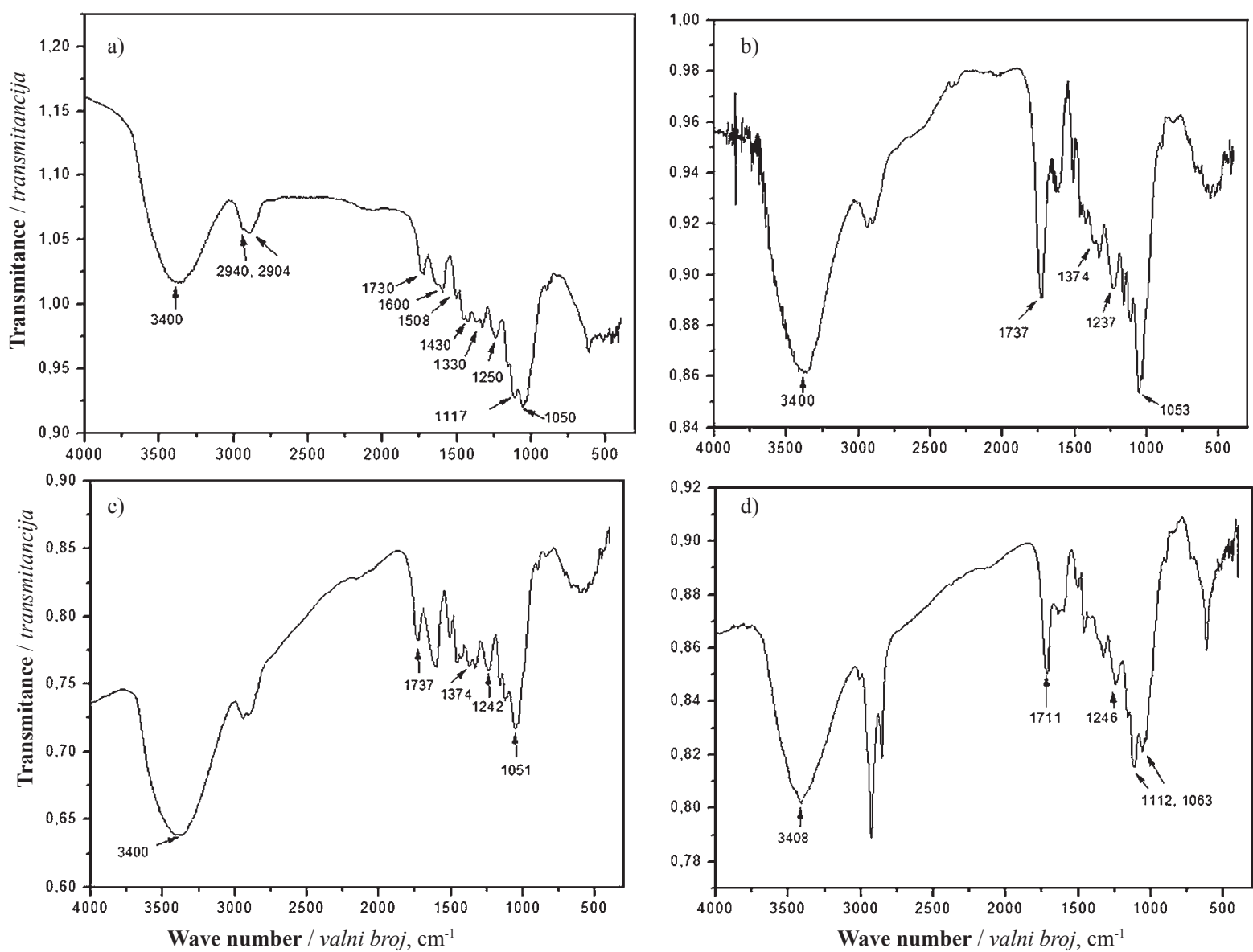

Figure 4 FTIR spectra: a) eucalyptus particles "in natura"; b) CA particleboards; c) TCA particleboards; d) RA particleboards Slika 4. FTIR spektri: a) prirodno iverje drva eukalipta; b) CA iverice; c) TCA iverice; d) RA iverice

Finally, RA bonded particleboards (Figure 4d) presented a prominent peak in $1711 \mathrm{~cm}^{-1}$ band, which is typical of $\mathrm{C}=\mathrm{O}$ groups of carboxylic acids. When compared to CA particleboards, RA bonded panels also presented a lower peak in the band $1737 \mathrm{~cm}^{-1}$. These results indicate a little or no esterification reaction that is related to the lack of adhesiveness in RA particleboards.

\section{CONCLUSIONS}

\section{ZAKLJUČAK}

The bio-based adhesives formulated with anhydrous citric acid and tannin-citric acid presented the capacity to bond eucalyptus particles into MDPs. Yet, ricinoleic acid cannot be used as an adhesive for particleboards based on the parameters used in this study.

The particleboards with anhydrous citric acid as adhesive presented the best physical and mechanical properties. For MOR, the MDPs met the requirements for the use in interior fitments, in dry conditions. For $M O E$ and $I B$, it met the requirements for the use of load bearing boards in humid conditions (EN 312, 2010).

The FTIRS analysis confirmed esterification reactions in tannin-citric acid and anhydrous citric acid bonded particles, which is related to the adhesives polymerization, and MDP that met the requirements as high as $\mathrm{P} 3$ grade for $M O E$.

\section{REFERENCES}

\section{LITERATURA}

1. Brum, S.; Bianchi, M.; Silva, V.; Gonçalves, M.; Guerreiro, M.; Oliveira, L., 2008: Preparation and characterization of activated carbon produced from coffee waste. Química Nova, 31 (5): 1048-1052.

2. Castro, G.; Alcântara, I.; Roldan, P.; Bozano, D.; Padilha, P.; Florentino, A.; Rocha, J., 2004: Synthesis, characterization and determination of the metal ions adsorption capacity of cellulose modified with $p$-aminobenzoic groups. Materials Research, 7 (2): 329-334. http://dx.doi.org/10.1590/S1516-14392004000200018.

3. Chupin, L.; Motillon, C.; Charrier-El Bouhtoury, F.; Pizzi, A.; Charrier, B., 2013: Characterization of maritime pine (Pinus pinaster) bark tannins extracted under different conditions by spectroscopic methods, FTIR and HPLC. Industrial Crops and Products, 49: 897-903. https://doi.org/10.1016/j.indcrop.2013.06.045.

4. Hergert, H., 1971: Lignins: occurrence, formation, structure and reactions. New York: J. Wile 1971, p. 267-297.

5. Kusumah, S.; Umemura, K.; Yoshioka, K.; Miyafuji, H., 2016: Utilization of sweet sorghum bagasse and citric acid for manufacturing of particleboard I: Effects of predrying treatment and citric acid content on the board properties. Industrial Crops and Products, 84: 34-42. https://doi.org/10.1016/j.indcrop.2016.01.042.

6. Liao, R.; Xu, J.; Umemura, K., 2016: Low density bagasse particleboard bonded with citric acid and Sucrose: effects of board density and additive content. BioResources, 11 (1): 2174-2185.https://doi.org/10.15376/biores.11.1.2174-2185. 
7. Mano, E.; Mendes, L., 1999: Introdução a polímeros. Edgard Blücher, São Paulo, Brazil. 208 p.

8. Pavia, D.; Kriz, G.; Lampman, G., 2008: Introduction to Spectroscopy. Fourth Edition. Brooks Cole. Washington, United States, $752 \mathrm{p}$

9. Péres, E.; Souza Jr, F.; Silva, F.; Chaker, J.; Suarez, P., 2014: Biopolyester from ricinoleic acid: synthesis, characterization and its use as biopolymeric matrix for magnetic nanocomposites. Industrial Crops and Products, 59: 260-267.

10. Randriamanantena, T.; Razafindramisa, F.; Ramanantsizehena, G.; Bernes, A.; Lacabane, C., 2009: Thermal behavior of three woods of Madagascar by thermogravimetric analysis in inert atmosphere. In: Proceedings of the Fourth High-Energy Physics International Conference, Madagascar, $10 \mathrm{p}$.

11. Santana, M.; Teixeira, D., 1996: Uso do bagaço de Canade-açúcar na confecção de chapas aglomeradas. Série Técnica, Brasília, DF: IBAMA, 36 p.

12. Seye, O.; Cortez, L.; Gómez, E., 2010: Estudo cinético da biomassa a partir de resultados termogravimétricos. In: Proceedings of the $3^{\text {th }}$ Encontro de Energia no Meio Rural. City, Campinas, Brazil.

13. Silva, D.; Lahr, F.; Garcia, R.; Freire, F.; Ometto, A., 2013: Life cycle assessment of medium density particleboard (MDP) produced in Brazil. The International Journal of Life Cycle Assessment, 18 (7): 1404-1411. https://doi.org/10.1007/s11367-013-0583-3.

14. Umemura, K.; Sugihara, O.; Kawai, S., 2013: Investigation of a new natural adhesive composed of citric acid and sucrose for particleboard. Journal of Wood Science, 3 (59): 203-208. https://doi.org/10.1007/s10086-013-1326-6.

15. Umemura, K.; Sugihara, O.; Kawai, S., 2015: Investigation of a new natural adhesive composed of citric acid and sucrose for particleboard II: Effects of board density and pressing temperature. Journal of Wood Science, 61 (1): 40-44. https://doi.org/10.1007/s10086-014-1437-8.

16. Umemura, K.; Ueda, T.; Kawai, S., 2012b: Characterization of wood-based molding bonded with citric acid. Journal of Wood Science, 58 (1): 28-45. https://doi.org/10.1007/s10086-011-1214-x.

17. Umemura, K.; Ueda, T.; Munawar, S.; Kawai, S., 2012a: Application of citric acid as natural adhesive for wood. Journal of Applied Polymer Science, 123 (4): 1991-1996. https://doi.org/10.1002/app.34708.

18. Vukusic, S.; Katovic, D.; Schramm, C.; Trajkovic, J.; Sefc, B., 2006: Polycarboxylic acids as non-formaldehyde anti-swelling agents for wood. Holzforschung, 60(4): 439-444. https://doi.org/10.1515/HF.2006.069
19. Widyorini, R.; Nugraha, R.; Rahman, M.; Prayitno, T., 2016: Bonding ability of a new adhesive composed of citric acid-sucrose for particleboard. BioResources, 11 (2): 45264535. https://doi.org/10.15375/biores.11.2.4526-4535.

20. Yang, C.; Xu, Y.; Wang, D., 1996: FT-IR spectroscopy study of the polycarboxylic acids used for paper wet strength improvement. Industrial \& Engineering Chemistry Research, 35 (11): 4037-4042. https://doi.org/10.1021/ie960207u.

21. Zagar, E.; Grdadolnik, J., 2003: An infrared spectroscopic study of H-bond network in hyperbranched polyester polyol. Journal of Molecular Structure, 658 (3): 143-152. https://doi.org/10.1016/S0022-2860(03)00286-2.

22. Zhao, Z.; Umemura, K.; Kanayama, K., 2015: Effects of the addition of citric acid on tannin-sucrose adhesive and physical properties of the particleboard. BioResources, 11 (1): 1319-1333.

23. ***EN 310, 1993: Wood-based panels. Determination of modulus of elasticity in bending and of bending strength. Brussels, Belgium, 6 p.

24. ${ }^{* * *}$ EN 317, 1993: Particleboards and fiberboards. Determination of swelling in thickness after immersion in water. Brussels, Belgium, $5 \mathrm{p}$.

25. ***EN 319, 1993: Particleboards and fiberboards - Determination of tensile strength perpendicular to the plane of the board. Brussels, Belgium, $6 \mathrm{p}$.

26. ***EN 312, 2010: Particleboards - Specifications. Brussels, Belgium, $20 \mathrm{p}$.

27. ***FAO, 2017: "Forest Products Statistics" (online). FAO Food and Agriculture Organization of the United Nations, www.fao.org/forestry/statistics/80938/en/. First published 2017 (Accessed Mar. 8, 2019).

28. ***IARC - International Agency for Research on Cancer, 2006: Formaldehyde, 2-Butoxyethanol. IARC Monographs on the Evaluation 88: 57-90.

29. ***IBÁ - Brazilian Industry of Trees, 2017: Technical Report 2017. São Paulo, Brazil, 79 p.

\section{Corresponding address:}

\section{DIVINO ETERNO TEIXEIRA, PhD}

Forest Products

Environmental Analyst at Forest Products Laboratory

Brazilian Forest Service

SCEN Trecho 2 Lote 4, 70818-900, Brasilia, BRAZIL e-mail: divinot@gmail.com 